\title{
LUCES Y SOMBRAS. MEDIOS DE COMUNICACIÓN. VERANO
}

\section{6}

\section{LIGHTS AND SHADOWS. MEDIA. SUMMER 2006}

Maribel Martínez Eder: Portavoz de FIATYR (Federación Ibérica de Telespectadores y Radioyentes) mm.eder@asociacionplazadelcastillo.org

\section{CURRÍCULUM VITAE}

Fundadora y presidenta de la Asociación Plaza del Castillo ATR Navarra de Usuarios de Medios de Comunicación, integrante de FIATYR (Federación Ibérica de Asociaciones de Telespectadores y Radioyentes). Fue miembro del Consejo Asesor de RTVE en Navarra.

\section{RESUMEN}

Las luces y las sombras en los medios de comunicación en lo que a programación se refiere. Diferentes ejemplos o casos al respecto en varios medios. Incluye un comunicado de la Federación Ibérica de Telespectadores y Radioyentes sobre la nueva normativa que obliga a las cadenas de televisión a anunciar su programación con once días de antelación. 


\title{
PALABRAS CLAVE
}

Medios de Comunicación - Programación - Normativa

\begin{abstract}
The lights and shadows in the media as far as programming is concerned. Different examples or cases on this in several ways. Includes a statement from the Viewers and Listeners Iberian Federation on the new legislation requiring television stations to announce its schedule of eleven days in advance.
\end{abstract}

\section{KEY WORDS}

Media - Schedule - Rules

\section{TEXTO}

\section{$\underline{\text { Las luces }}$}

- Se puede y se debe dar cabida a la excelencia en televisión: Las Noches Blancas, un programa de literatura en Tele-Madrid; es ameno e interesante; con participantes de gran altura intelectual y, por lo general, enorme capacidad de seducción. Además, en horario de máxima audiencia. Un lujo que todas las televisiones deberían ser capaces de copiar, así como copian sistemáticamente lo deleznable.

- El espacio "De cerca", dirigido y presentado por Baltasar Magro, un verdadero oasis que no defrauda: los entrevistados, personajes del más alto nivel. El hecho de que se emita por la segunda cadena y sin publicitar no ayuda, sin embargo, a su 
contemplación. Lo propio ha ocurrido con ipop, un espacio musical vanguardista y minoritario, retirado de la programación.

- Las palabras de D. Ignacio Buqueras, Presidente de la Comisión Nacional para la Racionalización de los Horarios, en la que FIATYR participa: "En Septiembre las televisiones considerarán adelantar las emisiones adaptándolas a horarios más humanos, más europeos".

- Sin despreciar a grandes artistas, sino todo lo contrario, una práctica muy sana y recomendable durante éste verano: cambiar de canal cada vez que se alude a las familias Ortega- Jurado; Muñoz-Zaldívar; Alba-Rivera-Pantoja; Janeiro-Campanario etc., sirve para desconectar de un alto porcentaje de la indescriptible programación televisiva veraniega.

- Las retrasmisiones deportivas: Formula 1, fútbol, baloncesto, tenis, ciclismo, motociclismo, etc. Por cierto, el deporte, también en verano, lo más visto.

- La vuelta de Estudio Abierto. Televisión Española recuperaría millones de espectadores si emitiese ciclos de calidad, coherentes (en horarios; ubicación), variados y estables; es uno de los espacios más añorados por los amantes del teatro televisado.

- La entrevista en El Semanal del Grupo Correo n 977, al gran actor escandinavo Max von Sydow; una perla: "Para la juventud de hoy en día, me parece que todo va por derroteros muy superficiales. La televisión necesita imágenes y lo devora todo. Si sales, eres famoso: es una de las ecuaciones más reduccionistas que puedan darse". 
- La disculpa del tabloide The Sun (del grupo editorial News Internacional, propiedad del magnate de la prensa australiana Rupert Murdoch) a la familia real británica por haber falseado una información.

- La correcta interpretación que hace Diario de Navarra (10 de Agosto), al reconocer la bajada de audiencia global en verano, por debajo del $20 \%$ de cuota de pantalla.

\section{Las sombras}

- Cuando se alude a un tema relacionado con el maltrato en el hogar, a los personajes que pueblan el circo rosa se les afilan los dientes; pues bien, sepan que no se reducirán, (de hecho se incrementan), los casos de violencia doméstica, mientras se sigan tratando de forma sensacionalista en televisión como se viene haciendo desde hace años. Inconveniente desde todos los puntos de vista, abrir los informativos y crear contenido (decenas de horas semanales) con la misma temática y los hechos más dramáticos.

- En contra de la voluntad de muchos y aún teniendo un sentido crítico muy desarrollado, es inevitable que el umbral de la permisividad se relaje progresivamente: sin apenas apercibirlo, vamos aceptando comportamientos extremadamente amorales, relativistas, violentos, como lo más natural del mundo. Parte de las series, reportajes e ilustraciones lo van imponiendo.

- No se puede explicar cuál es la razón para que TVE siga dando cabida (muy cuidada en cuanto a publicidad y ubicación) a los Morancos, cuando es un producto inapropiado para una televisión de titularidad pública por varias razones: están más vistos que el T.B.O., son estéticamente pésimos; groseros, cutres. Además, vienen fracasando ostensiblemente. Sólo se comprende si siguen manteniendo los contratos bloqueados que en otro tiempo disfrutaron. 
- Constatamos, lamentablemente, que en el terreno de la comunicación la clase política sigue sin estar a la altura de las circunstancias: el Gobierno de la Nación retrasando la Ley del Audiovisual que prometió para antes del verano; liberalizando más todavía la Ley de Contraprogramación; ignorando los incumplimientos del Código de Autorregulación736, en el pasado mes de Marzo (III Informe A.T.R.Villanueva); El Gobierno de la Comunidad de Madrid disolviendo el Consejo del Audiovisual... Y así hasta el infinito.

\section{Comunicado de FIATYR}

Maribel Martínez Eder, Portavoz de FIATYR. (Madrid 28-7-2006)

www.asociacionplazadelcastillo.org

Desde la Federación Ibérica de Telespectadores y Radioyentes (FIATYR), deseamos hacer llegar a la opinión pública, nuestro rechazo más contundente a la flexibilización de la normativa que obligaba a las cadenas de televisión a anunciar las programaciones con once días de antelación(la adaptación de la directiva más permisiva de Europa).

La nueva disposición (tres días) supone, en la práctica, legalizar la contraprogramación, con el consiguiente perjuicio para el espectador.

Las explicaciones que hemos podido escuchar de algunos responsables políticos son inadmisibles, refiriéndose a que no se cumplían los once días preceptivos. Efectivamente, somos los espectadores más desprotegidos de Europa: la normativa en ámbitos fundamentales no se cumple, ni existe ningún organismo que lo sancione en su caso, tal y como ocurre en todos los países desarrollados del mundo. 
Constatamos una vez más, que se viene actuando en beneficio de las empresas multimedia y en contra de los derechos de los espectadores. 